\title{
UNIVERSITYOF
}

FORWARD

THINKING

WESTMINSTER用

WestminsterResearch

http://www.westminster.ac.uk/westminsterresearch

Engaging with China's Soft Power in Zimbabwe: Harare Citizens'

Perceptions of China-Zimbabwe Relations

Mano, W.

Mano, W. (2016) Engaging with China's Soft Power in Zimbabwe: Harare Citizens' Perceptions of China-Zimbabwe Relations, in: Zhang, X., Wasserman, H. and Mano, W. (eds.) China's Media and Soft Power in Africa, pp. 163-180, Palgrave Macmillan. Reproduced with permission of Palgrave Macmillan.

This extract is taken from the author's original manuscript and has not been edited. The definitive, published, version of record is available here: [insert URL for product on http://www.palgrave.com/gb/book/9781137545657

The WestminsterResearch online digital archive at the University of Westminster aims to make the research output of the University available to a wider audience. Copyright and Moral Rights remain with the authors and/or copyright owners.

Whilst further distribution of specific materials from within this archive is forbidden, you may freely distribute the URL of WestminsterResearch: ((http://westminsterresearch.wmin.ac.uk/)).

In case of abuse or copyright appearing without permission e-mail repository@westminster.ac.uk 


\title{
Chapter 12
}

\section{Engaging with China's Soft Power in Zimbabwe: Harare Citizens' Perceptions of China-Zimbabwe Relations}

\author{
Winston Mano
}

\section{Introduction}

Research and debate on the emerging Sino-Zimbabwean relations have mainly focused on the scope and size of China's economic presence but not on how China is perceived by African media and locals in places it is investing in (Banda, 2009). The official claims that China's interventions are benefiting Africans are being challenged by local accounts of opposition to China's increased presence. This chapter focuses on how China's soft power is perceived and received in Zimbabwe, a key transitional nation with an official "Look East" policy. By analyzing views of "ordinary" citizens in Harare, Zimbabwe's capital city, on the subject of China's interventions, this research provides a unique account of the emerging Sino-Zimbabwe relationship.

While the official view seems cozy and positive, non-official perspectives tend to be critical of Beijing's actions and policies, seeing them as narrowly benefiting China and Zimbabwean ruling elites. On the one hand, critics of China, as seen from this research, view its intervention as contradictory, unethical, short term, exploitative, and overall as one that places Beijing's economic and political interests over ordinary people's human rights. On the other hand, supporters of China are enthusiastic about beneficial development projects. In discussing the results of the survey of Harare respondents, the research invokes Nyamnjoh's (2012) allegory of the "blind men and an elephant," in which perceptions can be influenced by prior assumptions, lack of familiarity, and prejudices.

\section{Chinese Soft Power and Interventions in Zimbabwe}


At Harare International Airport, the "Welcome to Zimbabwe" signs in Chinese are a clear indication that China has been accepted at the official level. By June 2015, an estimated 60 Chinese companies were operating in Zimbabwe, including those in the media and cultural sectors. Muronzi (2014) observes that Zimbabwe's Look East policy is both "politically motivated and a response to economic imperatives in the absence of investment and donor support from the West." The policy was introduced after the launch of the Forum of ChinaAfrica Cooperation (FOCAC) in 2000. FOCAC itself is described by Chinese scholars as representing "a new cooperation model between China, the world's largest developing country and Africa, the continent with the highest number of developing countries. Thus, this cooperation model could provide a new basis for solving global poverty" (Li Anshan et al., 2012, p. 9). It is part of a broader Chinese global strategy that emphasizes "multilateralism" and "South-South coalition" building. On the Zimbabwean side, the policy shift came after the Robert Mugabe-led government fell out with mainly the British and the Americans, following a disputed presidential election in 2002, seen as unfair at the start of the fast-track land reform process (Scoones et al., 2011). "We have turned East where the sun rises, and given our backs to the West where the sun sets" was how Mugabe reaffirmed the Look East policy on Independence Day in 2005 (Muronzi, 2014).

The Look East policy has enabled Zimbabwe to attract more business from China. ${ }^{1}$ Following a June 2006 visit to China by Joyce Mujuru, then Vice President of Zimbabwe, energy, mining, and farming deals worth billions of dollars were agreed with the Chinese. After 2007, major deals included a \$200 million purchase of a 92 percent stake in Zimasco Consolidated Enterprises Limited by Sinosteel Corp, China's biggest chrome importer. The Chinese have also invested in diamond mining through Anhui, a joint venture between the government's Zimbabwe Mining Development Company, the military, and the Chinese company. China Machine-Building International Corporation has signed a $\$ 1.3$ billion agreement to mine coal and build thermal power generators in Zimbabwe. These are but a few examples of the many deals between the two countries after the Look East policy. Foreign direct investment from China to Zimbabwe was between $\$ 35$ million and \$45 million annually between 2008 and 2010, and trade volumes between China and Zimbabwe rose from \$310 million in 2003 to \$1.1 billion in 2014. It is also important to note that Zimbabwe is "only ranked 26th out of 58 African countries trading with China [. . . Zimbabwe’s exports to China in 2013 were $\$ 688$ million, 
while China's exports to Zimbabwe were \$414 million. Chinese investment in Zimbabwe is \$602 million. Zimbabwe has been able to get preferential, concessionary and commercial loans from China in recent years amounting to \$1 billion" (Muronzi, 2014). Other Chinese-funded public projects include the $\$ 100$ million National Defence College just outside Harare, the \$144 million Harare water project, medical equipment for hospitals, Victoria Falls airport expansion, and the Kariba South hydropower expansion. From 2011 to 2014, Chinese official assistance to Zimbabwe stood at $\$ 100$ million. Even though these projects have had different levels of success, clearly China had brought significant investments into Zimbabwe at a time when it was facing significant economic sanctions.

Those critical of China have raised concerns about asymmetrical benefits and unethical business practices in the emerging relations. The critics of the Look East policy argue that Chinese companies are given preferential treatment by the government, often at the expense of opportunities for other business players, resulting in Zimbabwe losing revenue in uncollected taxes. The Chinese businesses underpay locals and also hire managers from China even though locals are equally or more experienced. There are also cases where the Chinese are thought to be flouting Zimbabwean tax regulations, undermining the rebate application process. "These revelations have brought Chinese-Zimbabwean relations under the microscope with some citizens [. . .] describing the economic relations between the two countries as that of a 'rider and horse"" (Mkudu, 2015). Linked to this is also a criticism of China's failure to protect the rights of ordinary Africans.

Despite building the headquarters of the African Union in Addis Ababa at a cost of $\$ 150$ million, China's public diplomacy on the continent is perceived by some Africans negatively. For example, China's use of power and veto is thought to have seriously undermined the cause of democracy in Darfur and Zimbabwe:

African civic groups need to start mobilising people to confront the Chinese government by demonstrating [. . . ] against its activities in Zimbabwe and Darfur. The people of Africa must not allow China to claim that it will always maintain a policy of non interference and the respect for sovereignty of African countries, yet be more than ready not only to illegally export weapons to African dictatorships, but also use its veto powers in the Security Council to block any punishment 
intended for those who commit crimes against humanity in the continent. (Moyo L., 2009)

The above radical view, in this case from a blogger, represents barriers to Chinese power, which exist among some Zimbabweans. It represents the gap between reality and perception of Chinese power as it interacts with civic groups and ordinary Zimbabweans.

To study the diverse perceptions of China in Harare, the chapter deploys the allegory of the "blind men and an elephant" as used by Nyamnjoh (2012). The attraction of the allegory is in how it questions different ways of knowing, in this case China, based on first-hand experience as opposed to merely contending with secondary narratives about something. In Nyamnjoh's version of this folktale, which exists in many cultures, what is significant is that the blind men collaborate and are full of anticipation "as the merchant who offers to take them to an elephant leads the way. They each contemplate and imagine how they will touch the elephant. The merchant coordinates and controls the encounter like a scientist conducting a laboratory experiment" (p. 64). The merchant's role in shaping perceptions is significant for this study as both local and international media have sought to frame the discourse on China to Zimbabweans. In the allegory, the first blind man touched the left foreleg of the elephant and exclaimed, "So the queer animal feels like that!" The merchant led the second to the rear of the elephant, upon which he touched the tail and exclaimed: "Ha! Truly a queer animal! Truly odd! I know now. I know." The third man touched the elephant's trunk, "which moves back and forth, turning and twisting," and thought, "That's it! I've learned." When the three blind men got together to share and discuss their findings, they describe the elephant differently, according to what they touched, as "swinging back and forth," as "without branches" and shaped like a "snake." After their seemingly weird descriptions, unsurprisingly there was no conclusion because they had not thoroughly examined the whole elephant.

The focus of this allegory, according to Nyamnjoh, is not on physical blindness or sight, but on the ways of seeing and knowing: "We must grant that intimate encounters with the elephant, however, deep and convincing, are always approached from particular angles and perspectives, and that such encounters are further compounded by the dimensions of being an elephant that are beyond appearances" (Nyamnjoh, 2012, p. 65). The allegory is also similar to Hall's (1997) encoding and decoding model that reveals different ways in which audiences actively interpret media content based on their political, socioeconomic, and cultural circumstances. Hall's model 
can be linked to the above because the allegory also stands for "another kind of blindness - that which comes from preconceptions, prejudices and assumptions about what constitutes reality, a blindness of which all humans are guilty" (Nyamnjoh, 2012, p. 65).

In a way, the blind men tried to "frame" stories of their experiences with the elephant for the purpose of convincing each other. Frames "hold great power in setting the context for debate, defining issues under consideration, summoning a variety of mental representations, and providing the basic tools to discuss the issues at hand" (Pan and Kosicki, 1993, p. 70). The blind men questioned and challenged each other's frames because their readings were from particular angles and perspectives, and because such encounters were shaped by prior knowledge at guided their interpretations. As will be seen below, the perception of the Chinese by citizens of Harare is guided by their social position, their prior knowledge, prejudices, and lack of knowledge of Beijing. The findings discussed below clearly show the possibilities and limits of China's public diplomacy and soft power in one of its partner countries.

The research involved nonprobability sampling of ordinary citizens of Harare, from July to September 2014. For this process, a questionnaire, designed to address the core research objectives, was administered to Harare citizens on the basis of their accessibility and also by purposive judgment of the researcher. This method helped both the researcher and the participants save time, generated specific answers, and was generally more efficient in measuring the Sino-Zimbabwean relationship. The questionnaire was meant to maximize the relationship between the answers recorded and what the research wanted to measure, which in this case was how Chinese interventions were regarded by Zimbabweans who live in Harare.

Harare is the capital city and administrative hub of Zimbabwe. With 2.1 million people (16.2 percent of the national population), it is urban in character and is relatively more developed than all other provinces of the country. Unlike other cities in Zimbabwe, Harare has a significant industrial sector, a good road network, and other facilities such as schools, hospitals, tourism, and agriculture. The main development challenges faced by Harare include overpopulation; dilapidated roads and general infrastructure such as electricity, water, and sewer system; poor residential accommodation delivery; and social vices such as crime, gambling, and prostitution (Zimbabwe Parliament Research, 2011. Sino-Zimbabwean offices are located opposite the Reserve Bank of Zimbabwe, the country's central bank, along Samora Machel Avenue, which also has the President Mugabe's main offices. Harare has, in the past, been promised but has not 
fully benefited from projects involving China. Examples include the short-lived Chinese-made buses meant to ease the urban road transport problems. However, these buses easily broke down and never helped resolve Harare's deepening urban transport woes. Similarly, attempts by China to improve Harare's water, road, and energy facilities have not delivered. The city's roads have many potholes, broken traffic signals are common, and the city has experienced worsening electricity and water supply rationing. However, new Chinese restaurants such as The Great Wall of China are set to charm Harare citizens with exotic Chinese cuisine. The Long Cheng Plaza, for shopping and amusement, and the National Sports Stadium are prominent representations of Chinese soft power in Harare. The structures loudly "communicate" China's huge intentions in Harare. The state-controlled broadcaster, ZBC, and the state-owned telecommunications company, TelOne, which are both headquartered in Harare, have benefited from projects worth several millions funded by China’s Exim Bank. Most of the Chinese interventions have been hotly debated in the Zimbabwean media, and because citizens of Harare are exposed to more media sources than other Zimbabweans, they tend to hold alternative views from the rest of the country. For example, in national elections, Harare residents tend to vote for opposition political parties because of what they perceive as poor service from Mugabe's government. Apart from recognizing the alternative nature of Harare's political makeup, one needs to locate China's soft power within a broader context.

\section{China's Media, Soft Power and Public Diplomacy}

China's soft power or public diplomacy in Zimbabwe, as in other countries, must be considered as multisided and as evident in areas such as health, culture, Confucius Institutes, environment, interparty communication, mass media, cultural exchanges, tourism, and youth development programs. Li Anshan et al. (2012, p. 25) note that China has enhanced its "media influence in Africa to challenge false international media reports about China-Africa cooperation, and issue news reports reflecting China's perspectives." They add that China's main news agencies have upped their role and African media personnel have been visiting China to attend training programs. The extent to which such public diplomacy, media, and cultural programs shore up China's power is debatable (Gagliardone et al., 2012; Wasserman, 2013; Li and Ronning, 2013). 
Apart from language problems and low cultural proximity between China and Africa, there is lack of experience and understanding of Beijing's media and culture. The lack of China's influence is partly to do with "traditional dependence on 'western media' for foreign news and global affairs and lack of knowledge of Chinese or Chinese society" (Kupe, 2013, p. 146). African media and "African public spheres [. . . ] have yet to produce a coherent theoretical response to the emergence of China and its media systems" (ibid, p. 146). The Zimbabwean context is, however, changing and could in the long run produce unexpected results for China's public diplomacy. Below I briefly consider the impact of China's soft power and the perceptions of China in other African countries.

\section{Perceptions of China in Other African Countries}

The role of China in Africa has so far received mixed perceptions, with Kenya leading in enthusiasm to do business with Beijing and South Africa and Nigeria harboring significant antiChina sentiments (Louw-Vaudran, 2014). For example, findings from a continental survey on the perception of China by Africans done by the Ethics Institute of South Africa (EthicsSA) "show that, of the 1,056 Africans from 15 countries surveyed, the majority were largely negative about Chinese business people in Africa (43.3 percent were negative and 35.4 percent positive), the quality of Chinese products and services (55.9 percent negative), and the economic and social responsibility of Chinese business (40.1 percent and 45.7 percent negative respectively).

Perceptions of the environmental responsibility of Chinese business (53.9 percent negative) and of their employment practices (46 percent negative) in Africa are bad. And labour practices are seen in a particularly poor light" (cited in Louw-Vaudran, 2014). The negative perceptions, especially from Nigeria and South Africa, were partly attributed to business investment rivalry and negativity in Western media reports. The findings echo other studies which identify complaints about Chinese traders and issues to do with inferior Chinese products. However, annual research conducted by the Pew Research Center shows that China, even though it receives negative coverage in Western media, is generally viewed in a positive light in most developing countries, including those in Africa (Pew Research Center, 2014). This could be a result of many things, including China's use of soft power. 
Perceptions of China in Zimbabwe, and in Harare in particular, were investigated because of the country's strategic importance to China. Zimbabwe's "Look East" policy was also a major factor. Beijing is also a topic of regular critical discussion in the Zimbabwean parliament and across its media. As will be seen below, China is seen as both a panacea and a hindrance to Zimbabwe's development. For example, in a contribution to the press, Eddie Cross (2013), a leading member of the MDC (Movement for Democratic Change) opposition party, makes a very interesting comparison of the economic development of the two countries: "China has the second largest economy in the world and although it is still poor in per capita terms, has lifted half its population out of poverty and created a vast middle class." He contrasts China's spectacular success with the mounting challenges in Zimbabwe: "By contrast Zimbabwe['s] [. . .] industrial base has shrunk to a quarter of what it was 30 years ago and 70 percent of our population lives in absolute poverty [...] What did we do wrong?" Such media debates on China in Zimbabwe are frequent and are part of what influences public perceptions of China in Zimbabwe. Apart from local and international media perspectives, daily interactions with the Chinese in shops, as tourists, at work, and in various other cultural contexts have helped shape the perspectives. Future research can observe such interactions and measure the relationship.

Using the allegory of the blind men and the elephant, one can argue that the above view represents an understanding of the "elephant," that is China, from an alternative political perspective. As will be discussed below, Cross's perception is not isolated as it coincides with the views held by some Zimbabweans I interviewed. It is a critique based on local politics where an opposition leader is seeking to implicate the ruling party in failed management of the country. Local opposition politicians in Zimbabwe also question the increasingly warm relationship with China because of the way China ignores human rights violations by Mugabe's party. Trevor Ncube, publisher of the Zimbabwe Independent, The Standard, and the NewsDay is similarly critical of and skeptical about what China is doing in Zimbabwe and questions the level of financial help given to Zimbabwe: "The Chinese are streetwise. We expect them to conduct themselves in a businesslike manner. We know it's not humanitarian; they will earn a bit of interest." Those who write or speak in favor of China in the Zimbabwean mainstream media include the Chinese ambassador's office, Zimbabwe government ministers, and bloggers who are sympathetic to the ideology of the ruling party. Very close to the folktale of the elephant, their view of China seems to be based on a long-term vision, together with pragmatism. 


\section{Doing Fieldwork in Harare}

The objectives of the nonprobability survey, from July to September 2014, was to measure perceptions and seek explanations to the Zimbabwe-China relations by those who live and work in Harare. The survey variables included data on the respondents as well as their attitudes and opinions. The "opinions" variable recorded how the respondents felt about Chinese interventions in Zimbabwe and the extent to which media reported on whether or not Zimbabwe was benefiting from its relations with China. The survey involved 100 respondents who were purposively selected around Harare. Consent was sought and they were briefed on the objectives of the research and assured of their right to confidentiality. The survey was conducted against a background of continuing economic hardships in Zimbabwe. Since 1997, Zimbabwe has been experiencing a multiplicity of socioeconomic challenges. The government-controlled media blames challenges facing Zimbabwe on what it calls sanctions imposed by the United States and the European Union while privately controlled media and some sections of civil society and the general populace generally blame the country's socioeconomic challenges on poor economic management by Mugabe's government. The state-controlled media such as the Herald repeatedly claim that Zimbabwe is immensely benefiting from relations with China. On their part, privately owned media such as the Daily News and the NewsDay perceive Zimbabwe as a "new colony" of China with a "horse" and "rider" relationship, whereby China is the rider and Zimbabwe the horse. The media coverage reflects and affects political party ideologies, complicating the ethical framework within which to observe the emerging Zimbabwe-China relations.

The question of whether or not Zimbabwe is benefiting from its relations with China was largely viewed in economic terms. To many respondents, the Chinese interventions in Zimbabwe were economically motivated, with China benefiting at the expense of Zimbabwe. On media coverage, the majority felt that privately owned media, as opposed to those which are government controlled, were more objective and truthful in their reportage on issues pertaining to Zimbabwe-China relations. It is in this regard that the survey sought to measure the views on Zimbabwean media. It was concerned with perceived objectivity and truthfulness in the coverage of China-Zimbabwe relations.

The survey had both open- and close-ended questions on the growing China-Zimbabwe relations to enable respondents to express themselves more clearly. It sought to measure the 
response to how selected Zimbabwean print media cover issues pertaining to the SinoZimbabwean relations. The 100 Harare respondents were from mixed backgrounds, including professionals, business people, gardeners, security guards, and a soldier. Among the 100 respondents, 53 were males and 44 were females. Three of the respondents did not indicate their gender, which could have been an omission on their part. Figure 12.1 indicates the response structure in relation to gender.

<COMP: INSERT FIGURE 12.1 HERE>

\section{Findings}

The analysis of the findings is presented below in terms of themes based on questions asked and how they were responded to:

\section{Responses to Whether Zimbabwe-China Relations are Mutually}

\section{Beneficial}

Of the 100 respondents analyzed, 98 (98 percent) did not consider the Zimbabwe-China relations as mutually beneficial. The majority were of the view that China was using Zimbabwe to service its own markets: exploit the natural resources of Zimbabwe and only sustain the booming Chinese economy. A tiny percentage, 2 percent of the respondents, was of the view that the relationship between Zimbabwe and China was "mutually beneficial." For them, the Chinese were playing a part in "reviving the Zimbabwean economy" and were providing locals with the much-needed economic resources, including "jobs and cheaper" commodities. The majority of Harare residents clearly did not consider Chinese interventions as beneficial.

\section{Perception of Zimbabwe-China Economic Relations}

The economic theme generated many anti-China views. As per the findings of the survey in Figure 12.2, only a small section of Harare residents felt that Zimbabwe was benefiting from its 
relationship with China. The dominant view saw exploitation, as graphically represented in Figure 12.2.

\section{<COMP: INSERT FIGURE 12.2 HERE>}

The responses to the survey, as shown in Figure 12.2, illustrate that the majority of Harare residents see the relationship with China as a "one-sided friendship" in which the Chinese are mainly interested in the expansion of their economy by way of creating foreign markets for goods produced in China.

Responses clearly indicated that Harare residents see the Chinese as being more concerned about exploiting Zimbabwe's natural resources, making "use of the abundant cheap labor" in the country and "depositing shoddy commodities" into the Zimbabwean market. As opposed to helping the Zimbabwean economy recover, most respondents felt that the Chinese are only interested in "quick profits" and in leveraging their own economic interests. Even those who were of the view that Zimbabwe is economically benefiting from its relations with China were also convinced that the benefits were more for China. For example, some of the respondents who said Zimbabwe was economically benefiting from China also alluded to "economically harmful practices" by the Chinese, such as not banking money in Zimbabwe, "underpaying employees," "shady deals with government," and "lack of investment in infrastructure and social services." Some of those who said Zimbabwe is benefiting were of the view that the benefit is largely in the retailing sector. This view tends to coincide with that of those who think that the Chinese are not contributing to economic growth as they are more interested in having Zimbabwe as a market for their own industries in China. In terms of the allegory of the blind men and the elephant, the above views illustrate different readings based on information from media and experience in dealing with China. Table 12.1 presents comments from some selected respondents.

<COMP: INSERT TABLE 12.1 HERE>

Farmers probably see greater hope in dealing with China because of emerging market opportunities for cash crops.

\section{Attitudes to the Teaching of Mandarin in Zimbabwe}

The survey also sought views on the teaching of the official Chinese language, Mandarin, at some educational institutions in Zimbabwe. There was a specific question relating to this and the 
majority of respondents felt that Mandarin should not be taught in Zimbabwe. The Harare respondents' attitudes to the question of whether or not the Chinese language should be taught in Zimbabwe are indicated in Figure 12.3.

\section{<COMP: INSERT FIGURE 12.3 HERE>}

As can be seen from Figure 12.3, 65 percent of the Harare respondents were of the view that Mandarin should not be taught in Zimbabwe on the grounds that "it is not an international language" and cannot be used in a wider context. The few who felt that the Chinese language should be taught in Zimbabwe were of the view that teaching Mandarin is necessary for "better business and cultural interaction" with Beijing. The other view was that Mandarin should be taught in Zimbabwe on the basis that China is an emerging global superpower with great potential for Zimbabwe. Perceptions and attitudes to Mandarin were probably influenced by First Lady Grace Mugabe when she revealed in 2007 that she had enrolled to study Mandarin at the People's (Renmin) University of China in a four-year program. She stayed in China during this time and completed her degree in 2011 ("Grace Mugabe," 2014).

The Harare respondents' reluctance to approve the teaching of Chinese was also born out of their earlier mistrust, emanating from negative perceptions on how China conducted its business with Zimbabwe. While most of the respondents believed that China is mainly interested in exploiting Zimbabwe economically, they also felt that the teaching of Chinese language is an avenue for strengthening this exploitative relationship.

\section{Views on How Zimbabweans Could Benefit More from Zimbabwe-}

\section{China Relations}

The Harare respondents felt that Zimbabwe-China relations could be improved if the Chinese genuinely focused their attention on investing in the revival and growth of Zimbabwe's

manufacturing sector. Respondents noted that the problem with the current situation was that the Chinese were simply exploiting Zimbabweans through "dumping cheap goods from China," "illtreating Zimbabwean employees," and "cheaply extracting Zimbabwean raw materials." It was also strongly felt that relations could be improved and become more beneficial if economic deals between the Zimbabweans and the Chinese were conducted in a more "transparent and inclusive 
manner." This was expressed against the background in which most of the business deals between the Zimbabwean government and the Chinese were being concluded in a manner that "violated" Zimbabwe's tender procedures. Some respondents also felt that relations could be improved if the Zimbabwean government consults with a cross-section of Zimbabwean citizens before concluding business deals with the Chinese. From the responses given, it also appears that Zimbabweans would want to see better-quality goods being imported from China into Zimbabwe. This is in consideration of how most respondents lamented that Chinese goods coming into Zimbabwe are substandard.

\section{Perceptions of Zimbabwean Media Coverage of China-Zimbabwe}

\section{Relations}

Harare residents have better access to media than all the other citizens in the country and were therefore suitably qualified to judge the character, tone, and quality of coverage of SinoZimbabwean relations in the local media. Their most prevalent view was that the privately owned media in Zimbabwe such as The Standard, Zimbabwe Independent, Daily News, and NewsDay were more accurate in their reportage on issues to do with Zimbabwe-China relations than was the case with state-controlled media such as The Herald. Based on the media mentioned, the findings of the survey showed how respondents ranked the accuracy of the national media in their reportage on Zimbabwe-China issues as presented in Figure 12.4.

\section{<COMP: INSERT FIGURE 12.4 HERE>}

The rankings for accuracy were on a scale of 1-10, with 1 being the most accurate and 10 being the least accurate. The respondents also added explanations. While some of the Harare respondents did not indicate reasons for their rankings, there was a general observation that statecontrolled media were biased in their reportage of Zimbabwe-China relations as they tended to uncritically "state the government position" on these relations, without analyzing the real situation on the ground. However, there were a few respondents who indicated that "both privately controlled and government controlled media were biased" in their reportage on issues pertaining to Zimbabwe-China relations. A few of the respondents alluded to "the problem of media polarization on political grounds." There were also possible contradictions in the answers 
to the question. For instance, some respondents said The Herald and the state broadcaster ZBC were the most accurate in reporting on Zimbabwe-China relations while at the same time claiming that Zimbabwe was not benefiting from its relations with China. The overwhelming observation was that Zimbabwe was not benefiting from its relations with China and the view coincided with information from alternative media sources. Finally, a number of respondents chose not to respond to the question on media rankings, pointing out that "they did not follow the media." This supports the fact that media reports (or at least reports of the sampled media) are not necessarily the basis upon which Zimbabweans base their views on the country's relations with China. The media served as the merchant in the "blind men and the elephant" tale, discussed at the beginning of the chapter, in terms of producing perceptions of China. However, the perceptions did not entirely rely on the media.

\section{The Extent to Which Zimbabwe Benefits from Media and Cultural}

\section{Exchange Programs with China}

The greater number of Harare respondents surveyed felt that Zimbabwe was not benefiting from media and cultural exchange programs with China. They felt that the mainstream media in China did not have "much interest in Zimbabwe's cultural well-being." They felt that it is Zimbabwe that seems to be putting more effort in this regard, with not much being done by China. The emerging cultural relations were asymmetrical. From the responses given, it would seem that most respondents viewed media and cultural exchange programs from the perspective of economic exploitation, in which China is more interested in championing its economic interests rather than in improving cultural relations with Zimbabwe.

\section{Attitudes to Visiting China}

The research on the Harare residents' emerging perceptions of China-Zimbabwe relations also sought to measure the respondents' interest in visiting China. Regardless of the negativity of the relations, 83 percent of respondents indicated that they are interested in visiting China, with the most popular responses being for "business purposes," "tourism," and "getting an appreciation of 
the Chinese culture." The other 17 percent indicated that they preferred to visit other European countries and not China, with the reasons varying from person to person. The behavior showed that the respondents were able to separate the problems with bilateral relations from their own personal ambition. It is also a window for China to invite more Zimbabweans so that they can have a first-hand experience.

\section{Summary of Responses to Key Questions}

Table 12.2 is a summary of key responses to the main questions that were posed in the survey. It gives a synopsis of the respondents' views on the Zimbabwe-China relations minus their views on how different media cover issues pertaining to these relations.

\section{<COMP: INSERT TABLE 12.2 HERE>}

Table 12.2 shows that the Chinese interventions are not viewed positively. There is a lack of familiarity with the "elephant" and great suspicion of its behavior. The official narrative of a "win-win" friendship was strongly rejected by the Harare respondents who participated in the survey.

\section{Conclusions}

The emerging perceptions of China-Zimbabwe relations as shown by this survey, although involving a small sample, are indicative of lack of knowledge of and trust in the Sino-Zimbabwe relations. Although it is still early to conclude, as shown by the attitudes of Harare residents, Chinese media and cultural soft power in Zimbabwe have not produced the desired positive admiration for China. The Harare residents, to some extent, are reflective of a broader national sentiment, overwhelmingly viewing the relations between the two countries as non beneficial, which could be linked to failure or lack of progress in Harare-specific projects that affect the residents. Within the boundaries of this wide-ranging perception, some respondents described the Chinese as "parasitic" and others called China the "new colonial master," and such views were probably influenced by the media. It is the perspective on China's economic exploitation of Zimbabwe that has resulted in the general distrust of the Chinese to the extent that some of the 
respondents are cynical of everything to do with China, including cultural exchanges and learning of the Chinese language. However, the respondents who held a pro-China perspective pointed out that China is helping "revive" the Zimbabwean economy in the wake of the economic embargo imposed on the country by the West.

The reluctance to have Mandarin taught in Zimbabwe points to resistance, among those interviewed, to assimilate or integrate the Chinese in local society. There is a clear ambivalence and even reluctance to have cultural exchanges with the Chinese. As observed from the pattern of responses, this sort of perspective is, to a larger extent, shaped by the view that China's motive is to exploit Zimbabwe's resources and not to help develop the country's economy.

With respect to perceptions of media coverage of issues dealing with Zimbabwe-China relations, there was a widespread view that, when compared with the government-controlled press, Zimbabwe's privately controlled press is more accurate in its reportage on these relations. As can be observed, this widespread view is, however, caught up in the trap of media polarization on partisan political grounds. Only a few respondents pointed to this reality, in which both privately and state-controlled media are polarized in their reportage on issues dealing with Zimbabwe-China relations.

From the findings of this survey, it is clear that Zimbabwe-China relations are far from perfect. Although there is tolerance, the responses revealed deep-seated resentment of the Chinese by Harare residents. The media has mainly presented the Chinese as either friends and enemies and there exists a gap between reality and representations of China in the media.

This chapter concludes by asking whether China's soft power including its increasing infrastructural and technical support to the Zimbabwean media sector, mostly owned by the state, is having an impact on the power balance and in how it is received in transitional Zimbabwe. It is particularly crucial to determine the extent to which the above emerging perspectives on China manifest themselves among government officials, business people, journalists, workers unions, civil society leaders, and, especially, those who have been to China. It is also worth considering whether China's state-centered, one-actor model has helped advance its soft power in Zimbabwe. The ability of China to respect Zimbabwean interests and to create mutually beneficial links will help shape how China's interventions will be tolerated by Zimbabweans. In his allegory, Nyamnjoh (2012, p. 65) asks whether it is possible to achieve "the level of objectivity needed to see the elephant for what it truly is - a complex reality that cannot be reduced to its constituent 
parts." He also asks "whether it matters what the elephant has to say" (p. 65). There is a sense that China has been the elephant which Zimbabweans and other Africans will need to approach without prejudices and preconceptions. The ultimate point is that although Beijing is powerful, its power over its image is limited by other points of power. China is increasingly influencing the global discourse on development, but it is not shaping it as it wishes because of local challenges to its image and power.

Table 12.1 Selected Harare Residents' Comments on China-Zimbabwe Relations

\begin{tabular}{|c|c|c|c|c|}
\hline Occupation & Education & Gender & Age & $\begin{array}{l}\text { Summary of comments on China- } \\
\text { Zimbabwe relations }\end{array}$ \\
\hline Student & $\begin{array}{l}\text { Ordinary-level } \\
\text { secondary school }\end{array}$ & Female & 18 & $\begin{array}{l}\text { Not interested in visiting China; China } \\
\text { is "dumping substandard goods" into } \\
\text { Zimbabwe, "burdening" future } \\
\text { generations }\end{array}$ \\
\hline $\begin{array}{l}\text { Harare } \\
\text { council } \\
\text { worker }\end{array}$ & $\begin{array}{l}\text { Advanced-level } \\
\text { secondary school }\end{array}$ & Female & 35 & $\begin{array}{l}\text { "Hates" China for benefiting a lot } \\
\text { more than Zimbabwe; pro-China } \\
\text { tenders are "unfair" and China is not } \\
\text { concerned about "social problems in } \\
\text { Zimbabwe" }\end{array}$ \\
\hline $\begin{array}{l}\text { Secondary } \\
\text { school } \\
\text { student }\end{array}$ & $\begin{array}{l}\text { Ordinary-level } \\
\text { secondary school }\end{array}$ & Female & 19 & $\begin{array}{l}\text { Believes China-Zimbabwe is a "win- } \\
\text { win relationship" and that China can } \\
\text { benefit Zimbabwe in terms of tourism } \\
\text { and education }\end{array}$ \\
\hline $\begin{array}{l}\text { Civil society } \\
\text { leader }\end{array}$ & University & Male & 35 & $\begin{array}{l}\text { Asymmetrical benefits, Zimbabwean } \\
\text { political elites benefit more; deals lack } \\
\text { transparency; "Zimbabwe is being } \\
\text { short-changed and manipulated" by } \\
\text { China; however, Zimbabwe's } \\
\text { agriculture and mining sectors seem to } \\
\text { be benefiting from China }\end{array}$ \\
\hline Unemployed & Advanced-level & Female & 41 & China is "looting our resources"; \\
\hline
\end{tabular}




\begin{tabular}{|c|c|c|c|c|}
\hline & secondary school & & & $\begin{array}{l}\text { "Zimbabwe has not seen anything } \\
\text { good coming from China (sic)"; "They } \\
\text { underpay workers" }\end{array}$ \\
\hline Farmer & $\begin{array}{l}\text { Advanced-level } \\
\text { secondary school }\end{array}$ & Male & 38 & $\begin{array}{l}\text { China has brought investment; "China } \\
\text { is now being accepted as a true friend } \\
\text { of Zimbabwe" }\end{array}$ \\
\hline Student & $\begin{array}{l}\text { Advanced-level } \\
\text { secondary school }\end{array}$ & Female & 20 & $\begin{array}{l}\text { China is "exploiting raw diamonds" of } \\
\text { Zimbabwe }\end{array}$ \\
\hline Farmer & $\begin{array}{l}\text { College trained in } \\
\text { mining }\end{array}$ & Male & 52 & $\begin{array}{l}\text { Investment coming to Zimbabwe but } \\
\text { ratio is " } 80 \%-20 \% \text { " in favor of China }\end{array}$ \\
\hline Soldier & $\begin{array}{l}\text { Ordinary-level } \\
\text { secondary school }\end{array}$ & Male & 36 & $\begin{array}{l}\text { No tangible development; unfulfilled } \\
\text { promises; in the long run, Zimbabwe } \\
\text { could be "worse off than [under] } \\
\text { previous colonialism" }\end{array}$ \\
\hline Accountant & University & Male & 30 & $\begin{array}{l}\text { China assisted Zimbabwe during the } \\
\text { "struggle for liberation"; China is } \\
\text { helping Zimbabwe "revive its } \\
\text { economy" }\end{array}$ \\
\hline
\end{tabular}

Table 12.2 Harare Respondents' Emerging Perceptions of China-Zimbabwe Relations

\begin{tabular}{lll}
\hline Question & Yes (\%) & No (\%) \\
\hline Would you like more Chinese to come to Zimbabwe? & 30 & 70 \\
Is China doing more than it should for Zimbabwe? & 10 & 90 \\
Is China helping Zimbabwe's economy? & 40 & 60 \\
Is China undermining Zimbabwe's democracy? & 55 & 45 \\
Is China a true friend of Zimbabwe? & 35 & 65 \\
Would you like to live in China? & 16 & 84 \\
\hline
\end{tabular}

Figure 12.1 Number of Respondents as Classified by Gender

Figure 12.2 Percentage representation of how Zimbabweans view Zimbabwe-China relations

Figure 12.3 Perceptions on the Teaching of Mandarin in Zimbabwe 
Figure 12.4 Media Rankings in Terms of Accuracy of Reportage on Zimbabwe-China Relations

${ }^{1}$ Information about China's investment in Zimbabwe is not always available because some details are not made public. My information here is from Zimbabwe journalist Chris Muronzi's article (2014) "China consolidates stranglehold on Zim," August 29, 2014. Available at: http://www.theindependent.co.zw/2014/08/29/china-consolidates/ (accessed January 28, 2015).

Cross E. (2013) "Zim, China: 1980 And Now” in The Financial Gazette, 19 December 2013 available at: http://www.financialgazette.co.zw/zim-china-1980-and-now/ (Accessed 20 June 2015)

Kupe T. (2013) "Globalization from my African corner" in Media, Culture \& Society,; vol. 35, 1: pp. 139-146.

Li S. and Ronning H. (2013), "Winning Hearts and Minds: Chinese Soft Power Foreign Policy in Africa", available at: http://www.cmi.no/publications/file/4906-winning-hearts-and-minds.pdf (accessed 20 June 2015).

Mkudu M. (2015) “Chinese Firms Seen Flouting Zimbabwe Tax Laws”, New Zimbabwe, 6 June 2015, available at: http://www.newzimbabwe.com/business-23206-

Chinese+firms+flouting+Zim+tax+laws/business.aspx (Accessed 20 June, 2015).

Pan, Z, D. \& Kosicki, M, G. (1993) "Framing Analysis: an Approach to News Discourse" in Political Communication, Volume 10, pp. 55-75.

Scoones I., N. Marongwe, B. Mavedzenge, J. Mahenehene, F. Murimbarimba and C. Sukume (2011), Zimbabwe's Land Reform: Myths and Realities, Suffolk: James Currey

Zimbabwe Parliament Research (2011), Harare Provincial Profile, Harare, Parliament of Zimbabwe. 